\title{
PENGARUH PEMBERIAN PAKAN BUATAN DENGAN KADAR LEMAK YANG BERBEDA TERHADAP PERTUMBUHAN DAN SINTASAN BENIH IKAN JAMBAL SIAM (Pangasius hypophthalmus)
}

I Wayan Subamia, Ningrum Suhenda, dan Evi Tahapari

\begin{abstract}
ABSTRAK
Informasi mengenai kebutuhan lemak untuk spesies ikan tertentu sangat diperlukan karena lemak merupakan salah satu sumber energi yang paling banyak dipergunakan untuk kebutuhan metabolisme tubuh selain protein dan karbohidrat. Suatu penelitian telah dilakukan selama 6 minggu dengan tujuan mendapatkan kebutuhan lemak dalam pakan buatan untuk mendukung pertumbuhan dan sintasan benih ikan jambal siam. Rancangan percobaan yang dipergunakan berupa rancangan acak lengkap dengan perlakuan pakan buatan dengan kandungan lemak berbeda (4\%,6\%, $8 \%, 10 \%$, dan $12 \%$ ). Sebagai ikan uji yaitu benih ikan jambal siam (Pangasius hypophthalmus) dengan bobot awal rata-rata $1,52 \mathrm{~g}$. Ikan uji dipelihara dalam tangki serat gelas dengan ukuran $60 \times 40 \times 50 \mathrm{~cm}^{3}$ dan padat penebaran 1 ekor/L. Jumlah pakan yang diberikan per hari yaitu $5 \%$ dari bobot tubuh pada 3 minggu pertama dan $4 \%$ untuk 3 minggu selanjutnya, dengan frekuensi pemberian pakan 5 kali per hari. Hasil penelitian menunjukkan bahwa pakan buatan dengan kadar lemak $4 \%$ cukup untuk mendukung pertumbuhan dan sintasan ikan dengan hasil sebagai berikut: pertumbuhan bobot rata-rata individu $(6,39 \mathrm{~g})$, retensi lemak $(41,34 \%)$, sintasan $(98,0 \%)$, dan nilai konversi pakan 1,09.
\end{abstract}

ABSTRACT: Thai catfish effect of dietary lipid levels on growth and survival rate of Pangasius hypophthalmus fry. By: I Wayan Subamia, Ningrum Suhenda, and Evi Tahapari

The study was conducted to evaluate the effect of different levels of dietary lipid on growth and survival rate of thai catfish $\boldsymbol{P}$. hypophthalmus fry. The fry with averaging individual body weight of $1.52 \mathrm{~g}$ were stocked in fiberglass tanks with stocking density of $1 \mathrm{fry} / \mathrm{L}$. The feed was given at $5 \%$ of body weight for the first three weeks and $4 \%$ for the three following weeks. Feeding frequency was five times a day. The result showed that the feed containing $4 \%$ lipid was enough growth and survival rate of $\boldsymbol{P}$. hypophthalmus fry gaining $6.39 \mathrm{~g}$ average individual weight gain $(6.39 \mathrm{~g})$, $41.34 \%$ lipid retention, $98.0 \%$ survival rate, and 1.09 feed convertion ratio.

KEYWORDS: $\quad$ lipid content, growth, lipid retention, Thai catfish (P. hypophthalmus)

\section{PENDAHULUAN}

Untuk menunjang keberhasilan pemeliharaan benih ikan jambal siam perlu diketahui aspek kebutuhan biologisnya antara lain mengenai kebutuhan nutrisi, baik kualitas maupun kuantitasnya. Dari segi kualitas, pakan sebaiknya mengandung unsur nutrien protein, lemak, karbohidrat, mineral, dan vitamin.

Beberapa penelitian yang pernah dilakukan untuk mendukung penelitian nutrisi benih ikan jambal siam di antaranya mengenai frekuensi pemberian pakan (Widjiastuti, 1989), pemberian pakan buatan pada umur yang berbeda (Subamia \& Kadarini, 2000), dan penelitian mengenai padat penebaran (Hasanah, 1989).

Penelitian kebutuhan nutrien benih ikan jambal siam untuk pengembangan budi dayanya telah dikemukakan oleh beberapa peneliti sebelumnya. Wahyuningsih (1988) melaporkan bahwa kebutuhan jenis pakan untuk benih ikan jambal siam yaitu $75 \%$ pakan alami dan $25 \%$ pakan buatan. Selanjutnya Zainudin (1998) telah dapat menentukan kebutuhan optimum kadar fosfor dalam pakan untuk benih ikan jambal siam yaitu antara 1,03\%--1,05\%. Dari penelitian Subamia \& Suhenda (2000) telah diketahui mengenai data kebutuhan protein yang tepat untuk pertumbuhan benih ikan jambal siam yaitu 35\%. Untuk kebutuhan nutrien ikannya seperti lemak untuk benih ikan jambal siam ukuran 1--2 inchi belum ada informasi yang diperoleh. Lemak merupakan sumber energi utama bagi ikan. Energi dalam pakan akan mempengaruhi laju pertumbuhan maupun tingkat sintasan benih ikan. Bila kadar energi pakan terlalu tinggi maka jumlah pakan yang dimakan ikan akan berkurang karena

\footnotetext{
-) Peneliti pada Balai Riset Perikanan Budidaya Air Tawar, Bogor
} 
kebutuhan energi metabolismenya segera terpenuhi, sehingga laju pertumbuhan benih ikan menurun. Kadar energi terlalu tinggi juga meningkatkan laju pengendapan (penyimpanan) lemak yang mungkin mengganggu fungsi hati, sehingga cenderung mengurangi sintasannya. Sebaliknya kadar energi yang terlalu rendah juga akan mengurangi laju pertumbuhan karena ikan akan memakai protein pakan untuk energi, sehingga efisiensi pembentukan (biosintesis) protein tubuh menurun. Oleh sebab itu, perbandingan (rasio) yang tepat antara protein dan energi dalam pakan untuk mendukung tingkat sintasan dan pertumbuhan ikan perlu diketahui (Rabegnatar \& Hidayat, 1972). Untuk itu, perlu dilakukan penelitian dengan tujuan mendapatkan nilai kebutuhan lemak dalam pakan buatan untuk mendukung pertumbuhan dan sintasan benih ikan jambal siam.

\section{BAHAN DAN METODE}

Penelitian ini dilakukan dengan menggunakan tangki serat gelas ukuran $60 \times 40 \times 50 \mathrm{~cm}$ sebanyak 15 buah yang diisi air 50 L/tangki dengan salinitas $3 \%$ Air yang digunakan adalah air sumur yang sebelum digunakan ditampung terlebih dahulu. Masing-masing wadah percobaan diberi aerasi dan dilengkapi penutup. Benih ikan jambal siam (Pangasius hypophthalmus) yang dipergunakan dengan bobot awal rata-rata individu 1,52 g ditebar pada masing-masing wadah sebanyak 1 ekor/L. Sebagai perlakuan adalah pakan buatan dengan kandungan lemak yang berbeda yaitu: 4\%, 6\%, 8\%, $10 \%$, dan $12 \%$. Komposisi pakan dan hasil analisis proksimat pakan uji disajikan pada Tabel 1 dan Tabel 2. Jumlah pakan yang diberikan per hari adalah $5 \%$ dari bobot total pada tiga minggu pertama dan $4 \%$ untuk tiga minggu selanjutnya.

Tabel 1. Komposisi pakan uji dengan kadar lemak berbeda

Table 1. Composition of experimental diets containing different lipid levels

\begin{tabular}{|c|c|c|c|c|c|}
\hline \multirow{2}{*}{$\begin{array}{l}\text { Bahan makanan } \\
\text { Ingredients }\end{array}$} & \multicolumn{5}{|c|}{$\begin{array}{l}\text { Kadar lemak pakan uji (\%) } \\
\text { Lipid level of the diets (\%) }\end{array}$} \\
\hline & 4 & 6 & 8 & 10 & 12 \\
\hline Tepung ikan (Fish meal) & 36.0 & 36.0 & 36.0 & 36.0 & 36.0 \\
\hline Bungkil kedelai (Soybean meal) & 33.0 & 33.0 & 33.0 & 33.0 & 33.0 \\
\hline Dedak halus (Rice bran) & 10.0 & 10.0 & 10.0 & 10.0 & 10.0 \\
\hline Tapioka (Cassava flour) & 7.6 & 7.6 & 7.6 & 7.6 & 7.6 \\
\hline Campuran mineral (Mineral premix) & 1.0 & 1.0 & 1.0 & 1.0 & 1.0 \\
\hline Campuran vitamin (Vitamin premix)' & 1.0 & 1.0 & 1.0 & 1.0 & 1.0 \\
\hline Minyak ikan (Fish oil) & 0.5 & 1.5 & 2.5 & 3.5 & 4.5 \\
\hline Minyak jagung (Corn oil) & 0.5 & 1.5 & 2.5 & 3.5 & 4.5 \\
\hline Alpha selulose (Filler) & 1.04 & 8.4 & 6.4 & 4.4 & 2.4 \\
\hline
\end{tabular}

Keterangan (Note) : * Campuran vitamin dan mineral tertera pada Lampiran 1 dan 2

* Vitamin and mineral premix indicated at Appendix 1 and 2

Tabel 2. Hasil analisis proksimat (berdasar bobot basah) pakan uji

Table 2. Nutrient content (as wet basis) of the experimental diets

\begin{tabular}{|c|c|c|c|c|c|}
\hline \multirow{2}{*}{$\begin{array}{l}\text { Nutrien } \\
\text { Nutrient }\end{array}$} & \multicolumn{5}{|c|}{$\begin{array}{l}\text { Kadar lemak pakan uji (\%) } \\
\text { Lipid level of the diets (\%) }\end{array}$} \\
\hline & 4 & 6 & 8 & 10 & 12 \\
\hline Air (Water) & 8.00 & 8.20 & 8.10 & 8.50 & 8.30 \\
\hline Protein kasar (Crude protein) & 35.41 & 35.50 & 35.81 & 35.22 & 35.46 \\
\hline Lemak kasar (Crude lipid) & 4.16 & 6.06 & 8.13 & 10.07 & 12.08 \\
\hline Abu (Ash) & 8.57 & 8.84 & 9.16 & 8.89 & 8.89 \\
\hline Serat kasar (Crude fiber) & 2.24 & 2.40 & 2.19 & 2.53 & 2.27 \\
\hline Bahan ekstrak tanpa Nitrogen (Nitrogen free extract) & 41.62 & 39.00 & 36.61 & 34.79 & 33.00 \\
\hline Energi (kkal/kg) (Energy) $(\mathrm{kcal} / \mathrm{kg})$ & $2,987.50$ & 087.60 & 217.603 & 310.60 & 453.20 \\
\hline Imbangan C/P (kkal/g) (Ratio C/P) (kcal/g) & 8.43 & 8.69 & 8.98 & 9.39 & 9.73 \\
\hline
\end{tabular}


Pakan diberikan dalam bentuk butiran halus dengan frekuensi pemberian pakan sebanyak 5 kali sehari yaitu pukul $08.00,10.00,12.00,14.00$, dan 16.00. Rancangan penelitian yang digunakan adalah rancangan acak lengkap (RAL) dengan 5 perlakuan dan 3 ulangan. Penggantian air dilakukan setiap pagi. Pengamatan pertumbuhan ikan dilakukan setiap minggu dengan pengambilan contoh ikan sebanyak $20 \%$ dari jumlah populasi setiap wadah. Penelitian dilaksanakan selama 6 minggu. Parameter yang diamati yaitu: pertumbuhan, konversi pakan, retensi lemak, dan sintasan. Sebagai pelengkap diamati pula sifat fisika dan kimia air.

\section{HASIL DAN BAHASAN}

Dari penelitian yang telah dilaksanakan selama 6 minggu diperoleh hasil bobot akhir ikan uji seperti tertera pada Tabel 3.

Pada Tabel 3 terlihat bahwa bobot akhir rata-rata individu yang paling tinggi diperoleh pada ikan yang diberi pakan dengan kadar lemak $4 \%$ yaitu $6,39 \mathrm{~g}$ dan yang paling rendah diperoleh pada ikan yang diberi pakan dengan kadar lemak $12 \%$ yaitu $5,14 \mathrm{~g}$. Hasil analisis statistik menunjukkan bahwa bobot akhir ikan uji antara perlakuan berbeda sangat nyata $(P<0,01)$. Pakan dengan kadar lemak $4 \%, 6 \%$, dan $8 \%$ memberikan pengaruh yang tidak berbeda terhadap bobot akhir ikan, akan tetapi berbeda dengan pakan yang mengandung kadar lemak $12 \%$.

Pada penelitian ini hasil yang diperoleh menunjukkan makin tinggi kadar lemak pakan menghasilkan bobot akhir yang makin rendah (Tabel 3). Tampaknya dengan pakan mengandung protein $35 \%$ dan kadar lemak $4 \%$ sudah cukup untuk memperoleh pertumbuhan yang baik bagi benih ikan jambal siam. Hal yang sama juga ditemukan oleh Seenappa \& Devaraj (1995) dalam penelitiannya di mana pertumbuhan ikan Indian major carps (Catla catla) yang diberi pakan dengan kadar lemak rendah $4 \%$ memberikan bobot akhir ikan yang lebih tinggi dibandingkan dengan yang diberi lemak $8 \%$ dan $12 \%$. Hasil penelitian Viola \& Rappaport (1979) menunjukkan bahwa dengan penambahan lemak $6 \%$ dalam ransum ikan mas dapat meningkatkan retensi protein dari $13 \%$ menjadi $20 \%$, sedangkan retensi energi $23,5 \%$ menjadi $30 \%$. Selanjutnya kadar lemak sebesar $10 \%$ dalam ransum catfish (semi purified diet) memberikan pertumbuhan yang optimum (Stickney, 1977). Hastings (1976) menyatakan bahwa ransum ikan yang baik adalah mengandung lemak antara $4 \%--18 \%$.

Peningkatan lemak pakan menyebabkan konsumsi makan ikan semakin rendah, sehingga membatasi jumlah nutrien yang masuk ke dalam tubuh yang pada akhirnya menurunkan pertumbuhan dan menyebabkan retensi lemak menjadi rendah (Tabel 4). Begitu juga kekurangan lemak yang terdapat dalam pakan akan menyebabkan protein digunakan sebagai sumber energi untuk metabolisme jelas bahwa kekurangan atau kelebihan energi dari lemak dapat menurunkan atau meningkatkan bobot ikan (Halver, 1988).

Pakan yang dimakan oleh ikan akan dipergunakan untuk pemeliharaan tubuh, metabolisme basal, aktivitas, dan pertumbuhan. Pertumbuhan terjadi apabila ada kelebihan energi bebas setelah energi yang tersedia dipakai untuk pemeliharaan tubuh, metabolisme basal, dan aktivitas. Sumber energi utama yang paling banyak dipergunakan untuk metabolisme adalah lemak. Dalam keadaan energi yang berasal dari lemak mencukupi maka energi yang berasal dari protein dipergunakan untuk membangun jaringan sehingga terjadi pertumbuhan.

Ikan makan untuk memenuhi kebutuhan energi sehingga kadar energi pakan menentukan jumlah pakan yang dimakan. Akibatnya energi pakan berpe-

Tabel 3. Bobot akhir rata-rata (g) ikan yang diberi pakan dengan kandungan lemak berbeda Tabel 3. Final average individual eight (g) of fish fed with different lipid levels of the diets

\begin{tabular}{cccccc}
\hline \multirow{2}{*}{$\begin{array}{c}\text { Ulangan } \\
\text { Replication }\end{array}$} & \multicolumn{5}{c}{$\begin{array}{c}\text { Kadar lemak pakan uji (\%) } \\
\text { Lipid level of the diets (\%) }\end{array}$} \\
\cline { 2 - 6 } & $\mathbf{4}$ & $\mathbf{6}$ & $\mathbf{8}$ & $\mathbf{1 0}$ & $\mathbf{1 2}$ \\
\hline 1 & 6.64 & 5.97 & 6.23 & 4.82 & 4.78 \\
2 & 6.50 & 6.42 & 6.00 & 5.41 & 6.44 \\
3 & 6.02 & 5.83 & 4.87 & 5.94 & 4.19 \\
\hline
\end{tabular}

Rata-rata (Average) $6.39 \pm 0.32^{\mathrm{a}} 6.07 \pm 0.30^{\mathrm{a}} 5.70 \pm 0.72^{\mathrm{a}} 5.39 \pm 0.56^{\text {at }} 5.14 \pm 1.16^{\mathrm{b}}$

Keterangan: Nilai rata-rata pada baris dengan huruf yang sama tidak berbeda nyata $(P>0,01)$ Note: Mean value in lines with the same superscript indicated no significant differences $(P>0.01)$ 
Tabel 4. Retensi lemak (\%) ikan yang diberi pakan dengan kadar lemak berbeda

Table 4. Lipid retention (\%) of fish fed with different lipid levels of the diets

\begin{tabular}{cccccc}
\hline \multirow{2}{*}{$\begin{array}{c}\text { Ulangan } \\
\text { Replication }\end{array}$} & \multicolumn{5}{c}{$\begin{array}{c}\text { Perlakuan kadar lemak (\%) } \\
\text { Treatment of lipid content (\%) }\end{array}$} \\
\cline { 2 - 6 } & 4 & 6 & $\mathbf{8}$ & $\mathbf{1 0}$ & $\mathbf{1 2}$ \\
\hline 1 & 40.65 & 31.26 & 21.53 & 11.92 & 11.10 \\
2 & 51.92 & 30.15 & 23.69 & 16.66 & 13.21 \\
3 & 31.41 & 27.21 & 19.94 & 10.97 & 13.69 \\
\hline
\end{tabular}

Rata-rata (Average) $41.33 \pm 10.29^{\mathrm{a}} 29.54 \pm 2.09^{\mathrm{ab}} 21.72 \pm 1.88^{\mathrm{bc}} 13.18 \pm 3.04^{\mathrm{c}} 12.66 \pm 1.37^{\mathrm{c}}$

Keterangan (Note): * Nilai rata-rata pada baris dengan huruf yang sama tidak berbeda nyata $(P>0,01)$

* Mean value in lines with the same superscript indicates no significant differences $(P>0.01)$

ngaruh terhadap pertambahan bobot, laju pertumbuhan, konversi pakan, dan penyimpanan lemak dalam tubuh (Nose, 1979). Protein, lemak, dan karbohidrat berperan sebagai sumber energi, bahan struktural tubuh, dan sebagai senyawa tertentu yang berperan dalam metabolisme tubuh (NRC, 1983). Lemak dapat menghasilkan energi yang lebih besar dibandingkan dengan protein dan karbohidrat. Nilai gizi lemak dipengaruhi oleh kandungan asam lemak, khususnya asam lemak esensial (Mustahal et al., 1995).

Setiap spesies ikan berbeda kebutuhannya akan protein dan energi. Hal ini dipengaruhi oleh umur/ ukuran dan jenis ikan. Hasil penelitian yang dilakukan menunjukkan bahwa pakan dengan kadar protein 35\% dan kadar lemak $4 \%$ serta imbangan energi dan protein $(\mathrm{C} / \mathrm{P})$ sebesar $8,43 \mathrm{kkal} / \mathrm{g}$ pakan, cukup untuk mendukung pertumbuhan dan sintasan benih jambal siam. Mokoginta (1995) melaporkan bahwa ikan gurami (Osphronemus gouramy) yang berukuran 0,27 $\mathrm{g}$ membutuhkan protein 43,39\% dan C/P $8 \mathrm{kkal} / \mathrm{g}$ pakan. Selanjutnya Saridewi (1998) melaporkan bahwa ikan nila (Oreochromis sp.) ukuran 2,43 g membutuhkan protein sebesar $31,22 \%$ dan C/P 8 kkal/ g. Begitu juga ikan sidat (Anguilla bicolor bicolor) membutuhkan C/P $8 \mathrm{kkal} / \mathrm{g}$ tetapi kebutuhan proteinnya $50 \%$ (Mahi, 2000). Hasil penelitian Kurnia (2002)menunjukkan bahwa ikan baung (Mystus nemurus) ukuran 5,3 g membutuhkan protein 29,1\% dan C/P 11,5 kkal/g. Untuk benih ikan bawal (Colossoma macropomum) membutuhkan protein $40 \%$ dan C/P 8,5 kkal/g (Adelina, 1999).

Peningkatan kadar lemak di dalam pakan pada penelitian ini menghasilkan retensi lemak yang semakin rendah. Retensi lemak rata-rata pada perlakuan pakan dengan kadar lemak 4\% menunjukkan nilai tertinggi yaitu 41,34\%; meskipun kadar lemak di dalam pakannya paling rendah (Tabel 4). Tubuh ikan akan membutuhkan lemak untuk disimpan sebagai lemak struktural. Untuk memenuhi kebutuhan lemak tersebut maka ikan menyintesis lemak berasal dari nutrien non-lemak. Pada Tabel 2 terlihat bahwa kadar karbohidrat pakan yang mengandung kadar lemak 4\% lebih tinggi $(41,62 \%)$, sehingga kemungkinan sintesis lemak berasal dari karbohidrat menjadi asam-asam lemak dan trigliserida yang terjadi di hati dan jaringan lemak (Linder, 1992).

Sintasan dari semua perlakuan berkisar antara 92\%--98,66\% (Tabel 5). Pada Tabel 5 terlihat sintasan

Tabel 5. Sintasan (\%) ikan yang diberi pakan dengan kadar lemak berbeda

Table 5. Survival rate (\%) of fish fed with different lipid levels of the diets

\begin{tabular}{cccccc}
\hline \multirow{2}{*}{$\begin{array}{c}\text { Ulangan } \\
\text { Replication }\end{array}$} & \multicolumn{5}{c}{$\begin{array}{c}\text { Perlakuan kadar lemak (\%) } \\
\text { Treatment of lipid content (\%) }\end{array}$} \\
\cline { 2 - 6 } & 4 & 6 & $\mathbf{8}$ & $\mathbf{1 0}$ & $\mathbf{1 2}$ \\
\hline 1 & 100 & 100 & 100 & 100 & 84 \\
2 & 100 & 100 & 100 & 100 & 92 \\
3 & 88 & 96 & 92 & 92 & 100 \\
\hline
\end{tabular}

Rata-rata (Average) $\quad 96 \pm 6.92^{\mathrm{a}} \quad 98.66 \pm 2.30^{\mathrm{a}} 97.33 \pm 4.61^{\mathrm{a}} 97.33 \pm 4.61^{\mathrm{a}} \quad 92.00 \pm 8.00^{\mathrm{a}}$

Keterangan (Note): * Nilai rata-rata pada baris dengan huruf yang sama tidak berbeda nyata $(P>0,05)$

* Mean value in lines with the same superscript indicates no significant different $(P>0.05)$ 
Tabel 6. Konversi pakan setiap perlakuan

Table 6. Feed conversion ratio of fish fed with different lipid levels of the diets

\begin{tabular}{cccccc}
\hline \multirow{2}{*}{$\begin{array}{c}\text { Ulangan } \\
\text { Replication }\end{array}$} & \multicolumn{5}{c}{$\begin{array}{c}\text { Perlakuan kadar lemak (\%) } \\
\text { Treatment of lipid content (\%) }\end{array}$} \\
\cline { 2 - 6 } & $\mathbf{4}$ & $\mathbf{6}$ & $\mathbf{8}$ & 10 & $\mathbf{1 2}$ \\
\hline 1 & 1.08 & 1.13 & 1.07 & 1.56 & 1.61 \\
2 & 1.01 & 1.08 & 1.14 & 1.10 & 1.35 \\
3 & 1.18 & 1.18 & 1.44 & 1.78 & 1.19 \\
\hline Rata-rata (Average) & $1.09 \pm 0.08^{\mathrm{a}}$ & $1.13 \pm 0.05^{\mathrm{a}}$ & $1.21 \pm 0.19^{\mathrm{a}}$ & $1.48 \pm 0.34^{\mathrm{a}}$ & $1.38 \pm 0.21^{\mathrm{a}}$ \\
\hline
\end{tabular}

Keterangan (Note): * Nilai rata-rata pada baris dengan huruf yang sama tidak berbeda nyata $(P>0,05)$

${ }^{*}$ Mean value in lines with the same superscript indicates no significant differences $(P>0.05)$

Tabel 7. Kisaran nilai sifat fisika dan kimia air selama 6 minggu pemeliharaan Table 7. Range of water physical chemical value during 6 weeks rearing periods

\begin{tabular}{lccccc}
\hline \multirow{2}{*}{$\begin{array}{c}\text { Parameter } \\
\text { Parameters }\end{array}$} & \multicolumn{5}{c}{$\begin{array}{c}\text { Perlakuan kadar lemak (\%) } \\
\text { Treatment of lipid content (\%) }\end{array}$} \\
\cline { 2 - 6 } & $\mathbf{4}$ & $\mathbf{6}$ & $\mathbf{8}$ & $\mathbf{1 0}$ & $\mathbf{1 2}$ \\
\hline Suhu air (Water temperature) $\left({ }^{\circ} \mathrm{C}\right)$ & $26--28$ & $26--28$ & $26--28$ & $26--28$ & $26--28$ \\
$\mathrm{pH}$ & $7.0--7.5$ & $7.0--7.5$ & $7.0--7.5$ & $7.0--7.5$ & $7.0--8.0$ \\
$\mathrm{O}_{2}(\mathrm{mg} / \mathrm{L})$ & $5.17--5.88$ & $5.22--5.41$ & $5.64--5.88$ & $6.00--6.47$ & $5.47--6.70$ \\
$\mathrm{CO}_{2}(\mathrm{mg} / \mathrm{L})$ & $4.39--5.24$ & $4.39--5.38$ & $4.39--5.59$ & $4.39--5.75$ & $4.39--6.53$ \\
$\mathrm{NH}_{3}(\mathrm{mg} / \mathrm{L})$ & $0.1--0.4$ & $0.1--0.5$ & $0.1--0.5$ & $0.1--0.5$ & $0.1--0.5$ \\
Salinitas (Salinity) (\%o $)$ & 3.0 & 3.0 & 3.0 & 3.0 & 3.0 \\
\hline
\end{tabular}

yang tinggi diperoleh pada ikan yang diberi pakan dengan kadar lemak $6 \%$ dan yang rendah diperoleh pada ikan yang diberi pakan dengan kadar lemak $12 \%$. Hasil analisis statistik menunjukkan bahwa sintasan antara perlakuan tidak berbeda nyata $(P>0,05)$.

Nilai konversi pakan yang terendah terdapat pada perlakuan dengan kadar lemak $4 \%$ yaitu 1,09 dan yang tertinggi pada perlakuan dengan kadar lemak $12 \%$ yaitu 1,38 (Tabel 6 ). Namun hasil analisis statistik menunjukkan bahwa nilai konversi pakan antara perlakuan tidak berbeda nyata $(P>0,05)$.

Pertumbuhan tidak dapat dipelajari tanpa melibatkan konsumsi makanan (Brett, 1979). Indikasi yang digunakan NRC (1977) untuk menentukan efektivitas pakan adalah besar kecilnya nilai konversi pakan atau efisiensi pakan. Tingginya konversi pakan menunjukkan penggunaan pakan untuk pertumbuhan kurang efisien. Dilihat dari nilai konversi pakan pada Tabel 6 menunjukkan bahwa pakan dengan kandungan lemak $4 \%$, konversi pakannya paling rendah yaitu 1,09 .

Kisaran nilai sifat fisika dan kimia air selama penelitian berlangsung disajikan pada Tabel 7. Pada
Tabel 7 terlihat bahwa kisaran $\mathrm{pH}(7,0--8,0)$, suhu air $\left(26^{\circ} \mathrm{C}--28^{\circ} \mathrm{C}\right), \mathrm{O}_{2}(5,17--6,70 \mathrm{mg} / \mathrm{L}), \mathrm{CO}_{2}(4,39--6,53$ $\mathrm{mg} / \mathrm{L})$, dan Amonia/ $\mathrm{NH}_{3}(0,1--0,5 \mathrm{mg} / \mathrm{L})$. Nilai-nilai ini masih berada dalam kisaran yang layak bagi kehidupan benih ikan jambal siam (Boyd, 1979).

\section{KESIMPULAN}

Hasil penelitian yang diperoleh menunjukkan bahwa pakan dengan kadar lemak $4 \%$ dan protein $35 \%$ cukup untuk mendukung pertumbuhan dan sintasan benih ikan jambal siam.

\section{DAFTAR PUSTAKA}

Adelina. 1999. Pengaruh Pakan dengan Kadar Protein dan Rasio Energi Protein yang Berbeda terhadap Pertumbuhan Benih Ikan Bawal (Colossoma macropomum). Tesis Program Studi Ilmu Perairan, Program Pascasarjana, Institut Pertanian .Bogor, 75 pp.

Boyd, C.E. 1979. Water Quality of Warmwater Fish Ponds. Auburn University. Auburn, Alabama, $359 \mathrm{pp}$.

Brett, J.R. 1979. Environmental factors and growth, dalam Hoar, MSI Randall and Brett J.R., (eds.) Fish Phy. 
Bioenergitic and Growth. Academic Press. London, 8: $280--344$

Halver, J.E. 1988. Fish Nutrition. Academic Press, INC, London $789 \mathrm{pp}$.

Hasanah, T. 1989. Pengaruh Tingkat Padat Penebaran yang Berbeda terhadap Pertumbuhan Benih Jambal Siam (Pangasius sutchi Fowler) yang Diberi Pakan Buatan dan Daphnia sp. Karya IImiah. Fakultas Perikanan, Institut Pertarian Bogor. 47pp.

Hastings, W.H. 1976. Fish Nutrition and Fish Feed Manufacture Rep. From FAO, FIR: AQ/Cont/76/R, 23. Rome, Italy, $13 \mathrm{pp}$.

Kurnia, A. 2002. Pengaruh Pakan dengan Kadar Protein dan Rasio Energi Protein yang Berbeda terhadap Efisiensi Pakan dan Pertumbuhan Benih Ikan Baung (Mystus nemurus C.V.). Tesis Program Studi IImu Perairan, Program Pascasarjana, Institut Pertanian Bogor, 54 pp.

Linder, M.C. 1992. Biokimia Nutrisi dan Metabolisme dengan Pemakaian secara Klinis. Departement of Chemistry, California State University, Fullerton. Penerjemah Aminuddin Parakkasi. UI Press. $781 \mathrm{pp}$.

Mahi, I.I. 2000. Pengaruh Kadar Protein dan Imbangan Energi Protein Pakan Berbeda terhadap Retensi Protein dan Pertumbuhan Benih Ikan Sidat (Anguilla bicolor bicolor). Tesis Program Studi IImu Perairan, Pascasarjana, Institut Pertanian Bogor, 55 pp.

Mokoginta, I. 1995. Kebutuhan nutrisi ikan gurami (Osphronemus gouramy) untuk pertumbuhan dan reproduksi. Laporan Penelitian, Fakultas Perikanan Institut Pertanian Bogor, $236 \mathrm{pp}$.

Mustahal, Bejo S., dan Pramu S. 1995. Pembenihan ikan laut di keramba jaring apung bagi budidaya laut. Prosiding Pusat Penelitian dan Pengembangan Perikanan, Jakarta, p. 197--203.

Nose, T. 1979. Diet composition and feeding techniques in fish culture with complete diets. In Halver, J.E. and K. Tlews, eds., Finfish nutrition and fishfeed. Proc. World Symposium EIFAC/FAO, ICES, IUNS. Hamburg, 20--23 June 1978. Berlin, p.124--134.

NRC (National Research Council). 1977. Nutrient Requirements of Warmwater Fishes. National Academy of Sciences. Washington, D.C., 86pp.

-. 1983. Nutrient Requirements of Warmwater Fishes and Shellfish. National Academy of Sciences. Washington, D.C., 102 pp.

Rabegnatar, I.N.S. dan W. Hidayat. 1972. Estimasi perbandingan optimal energi dan protein dalam pakan buatan untuk pembesaran benih lele (Clarias batrachus) dalam budidaya keramba jaring apung. Prosiding Seminar Hasil Penelitian Air Tawar 1991/ 1992, Balitkanwar, Bogor, p.18--28.

Saridewi, T.R. 1998. Pengaruh Kadar Protein yang Berbeda dengan Rasio Energi Protein $8 \mathrm{kkal} / \mathrm{g}$ Protein terhadap Kecernaan, Koefisien Resfirasi dan Ekskresi Ammonia Benih Ikan Nila Merah (Oreochromis sp.). Skripsi Fakultas Perikanan, Institut Pertanian Bogor, 42 pp.

Seenappa, D. and K.V. Devaraj. 1995. Effect of different levels of protein and carbohydrate on growth, feed utilization and body carcass composition of fingerling in Catla catla (Ham). Aquaculture, 129: 243-249.

Stickney, R.R. 1977. Role of nutrition in channel catfish farming. In R.R. Stickney and R.T. Lovell (Eds.). Nutrition in Channel Catfish. Southern cooperative series bull., 218: 5--60.

Subamia, I.W. dan N. Suhenda. 2000. Penentuan kebutuhan kadar protein pakan untuk pertumbuhan dan kelangsungan hidup benih ikan jambal siam (Pangasius hypophthalmus). Prosiding Seminar Nasional Keanekaragaman Hayati Ikan. Pusat Studi IImu Hayati IPB bekerja sama dengan Pusat Penelitian dan Pengembangan Biologi Lembaga IImu Pengetahuan Indonesia, p. 285--289.

Subamia, I.W. dan T. Kadarini. 2000. Pemberian pakan buatan pada benih ikan jambal siam (Pangasius hypophthalmus) dalam tingkatan umur yang berbeda. Prosiding Seminar Nasional Perikanan Penangkapan dan Budidaya Perairan, Fakultas Perikanan dan IImu Kelautan, Universitas Satya Negara Indonesia (USNI) Jakarta, p. 83--90.

Viola, S. and U. Rappaport. 1979. The "Extra Calorie Effect" of Oil in Nutrition of Carp. Barnidgeh, 31 (3): 51--69.

Wahyuningsih, M.R. 1988. Pengaruh Pemberian Campuran Pakan Alami dan Pakan Buatan dengan Perbandingan Berbeda terhadap Kelangsungan Hidup dan Pertumbuhan Benih Ikan Jambal Siam (Pangasius sutchi Fowler). Skripsi Sarjana Biologi. Fakultas Biologi, UNAS, Jakarta 47 pp.

Widjiastuti, M. 1989. Pengaruh Frekuensi Pemberian Pakan Kombinasi Daphnia sp. dan Pakan Buatan terhadap Pertumbuhan Benih Ikan Jambal Siam (Pangasius sutchi Fowler). Karya IImiah, Fakultas Perikanan, Institut Pertanian Bogor. 39 pp.

Zainudin. 1998. Kadar Fosfor Optimum dalam Pakan Benih Ikan Jambal Siam (Pangasius sutchi Fowler). Program Pasca Sarjana Institut Pertanian Bogor. 23 pp. 